\title{
A Transformação de Maria: um estudo sobre representações do feminino e construções identitárias na prática de danças ciganas
}

\author{
Cíntia Bueno Marques \\ Universidade Federal do Rio Grande do Sul - UFRGS, Porto Alegre/RS, Brasil \\ E-mail: cbmarques@hotmail.com
}

\section{Resumo}

A dança é uma forma de expressão rica em significados. Na cultura cigana, a música e a dança estão presentes, tanto como forma de expressão dos sentimentos, quanto como ritual de conexão com a natureza e com a espiritualidade. Homens e mulheres têm diferentes papéis representados nessa dança que refletem modos de ser, crenças e valores próprios. Tais representações são expostas, não somente pelo repertório de movimentos executados, mas pelo conjunto de elementos que compõem a cena da dança. Esse texto resulta da pesquisa desenvolvida como trabalho de conclusão do Curso de Especialização em Dança que teve como objetivo analisar representações do feminino, presentes nas danças ciganas e de que modo essas representações podem refletir transformações naqueles que as praticam. A partir da abordagem qualitativa, a pesquisa empregou observação participante e entrevista narrativa para a coleta de dados, no contexto específico pesquisado. Nesse sentido, não pretendeu produzir generalizações a partir do estudo, porém, foi possível a partir dos resultados apresentados, reconhecer o potencial da dança como tecnologia de si, para promover reflexões e desencadear transformações positivas.
The dance is a way of expression, that is rich in meanings. In Gypsy culture, music and dance are present, both as a way of expressing feelings and as a ritual of connection with nature and spirituality. Men and women have different roles represented in this dance that reflect ways of being, beliefs and values. Such representations are exposed, not only by the repertoire of moves executed, but by the set of elements that make up the dance scene. This text is the result of the research developed as conclusion work of the Specialization in Dance course that aimed to analyze the female representations, present in the Gypsy dances and how these representations may reflect transformations on those who practice them. From the qualitative approach, the research employed participant observation and narrative interview for data collection, in the specific context researched. In this sense, this research did not intend to produce generalizations from the study, however, it was possible from the results presented, to recognize the potential of dance as a technology from itself, to promote reflections and trigger positive transformations. 


\section{Apresentando O Estudo}

O visível é impregnado de invisível, e de tal modo que para compreender plenamente as relações visiveis é preciso ir até a relação entre o visível e o invisível. (MERLEAU-PONTY, 1982).

Há algum tempo, venho pesquisando sobre pedagogias culturais e identidades contemporâneas, dentro da área da Educação. Em 2016 realizei uma pesquisa de pós-doutorado que teve por objetivo analisar possíveis construções identitárias que se dão através das danças étnicas. Tais danças, marcadas por simbologias específicas, trabalham com representações de identidades étnicas, e estão relacionadas a um determinado contexto histórico-cultural que, por diferentes razões, interpelam os sujeitos e os transformam.

Para atender a esse objetivo, realizei uma pesquisa de cunho etnográfico num grupo de danças ciganas ${ }^{1}$, cuja professora é de etnia cigana $C A L O N^{2}$ e se propõe a disseminar a cultura cigana através da dança. Tornei-me membro desse grupo. Estudei, ensaiei, participei de apresentações, frequentei festas de acampamento, enfim, vivi experiências ímpares sobre as quais meus escritos ainda são insuficientes, considerando a riqueza de informações registradas nesse tempo.

1 Utilizo o termo "danças ciganas" no plural com o intuito de preservar a diversidade de ritmos e estilos contidos na dança desse povo. Considerando que estarei me referindo a um conjunto de danças praticadas na cultura cigana, seria um equívoco utilizar o termo no singular.

2 CALON é um dos grupos de etnia cigana que pode ser encontrado no Brasil. Costuma-se distinguir pelo menos três grandes grupos de ciganos: os ROM ou ROMA, que falam a língua romani e são predominantes nos países balcânicos, mas a partir do século XIX migraram também para outros países Europeus e para as Américas; os SIN$T I$, que falam a língua sintó e são mais encontrados na Alemanha, Itália e França; os CALON ou KALÉ, que falam a língua caló e vivem principalmente em Portugal e na Espanha, mas que no decorrer dos tempos se espalharam também por outros países da Europa e foram deportados ou migraram inclusive para a América do Sul. No Brasil predominam até hoje os ciganos CALON e ROM.
Nessa ocasião, conheci Maria ${ }^{3}$, que chegou ao grupo junto comigo e durante o período de um ano passou por visíveis transformações. Olhando para ela tive muitos insights! Comecei a refletir sobre como a dança cigana a interpelou e o que a esta prática tinha despertado nela. Falo em "despertar", pois o que observei em Maria pareceu aos meus olhos uma verdadeira "metamorfose". O que estava vendo não se restringia ao que fui pesquisar ali - identidades étnicas -, mas ultrapassava este tema, abrangendo uma relação bem mais profunda entre a dança em si e a mulher que ao dançar se transformava. O interesse pela história de Maria e por aprofundar meus conhecimentos sobre o que estava observando era inevitável.

No mesmo período em que concluí a pesquisa do pós-doutorado, estava cursando Especialização em Dança, e ao pensar na escrita do Trabalho de Conclusão de Curso, percebi a oportunidade de retomar a transformação de Maria, reconstituindo a pesquisa, sobre uma nova perspectiva. Nesse sentido, revisitei meus diários de campo, recordei momentos vividos, reestabeleci contato com Maria, construindo percursos de pesquisa que pudessem revelar a riqueza da relação que se estabeleceu entre Maria e a sua dança.

Assim, pretendo descrever aqui minhas descobertas acerca do tema, que se traduzem, em última análise, às descobertas de Maria sobre si, através da dança. Não se trata de um texto que propõe aprofundamento sobre a técnica da dança cigana, nem sobre a metodologia empregada no ensino dessa técnica. Tampouco se direciona a quem busca compreender os benefícios físicos desta prática, embora sejam inquestionáveis. $O$ texto a seguir fala de sentimento, de transformação, da experiência de si na relação com a dança. Trata da dança enquanto arte que interpela os sujeitos, os atravessa e nesse atravessamento, produz marcas e os transforma. Trata de buscar, como sugere Merleau-Ponty (1982) no trecho da epígrafe, compreender a relação entre o visível e o invisível. 3 Nome fictício que adotei para manter a identidade do
sujeito da pesquisa em sigilo. 


\section{Percursos metodológicos}

A pesquisa desenvolvida teve como objetivo analisar representações do feminino, presentes nas danças ciganas e de que modo essas representações podem refletir transformações naqueles que as praticam. Nessa perspectiva, busquei problematizar: Quais representações do masculino/feminino podem ser identificadas nas danças ciganas? De que modo tais representações interpelaram Maria? Que transformações podem ter sido desencadeadas a partir das representações do feminino na dança praticada por Maria? Como isso se evidenciou?

A partir da abordagem qualitativa, optei pela coleta de dados através da observação participante e da entrevista narrativa. Através destes procedimentos, tive a intenção de descrever o processo de transformação de Maria, analisando possíveis processos de subjetivação desencadeados a partir das representações de gênero trabalhadas na dança cigana.

A abordagem qualitativa tem como característica a busca de significados, a compreensão de fenômenos centrada na descrição, na análise e na interpretação das informações obtidas, de forma contextualizada (MOLINA NETO; TRIVIÑOS, 1999). Nesse sentido, é importante salientar que não busquei chegar a generalizações a partir do caso de Maria, mas sim, buscar possíveis articulações entre a prática da dança cigana, as representações femininas de uma cultura específica presentes nessa dança e as transformações que aconteceram com Maria no período de um ano. Segundo Molina Neto e Triviños,

na pesquisa qualitativa, o fundamental, na maioria das vezes, não é a quantidade de participantes a serem observados para validação do estudo, mas a observação em profundidade, por aportar elementos significativos de determinadas situações. (MOLINA NETO; TRIVIÑOS, 1999, p.70).
Tais elementos significativos serão o foco da pesquisa proposta, através do estudo da transformação de Maria.

Devido à necessidade de detalhamento e aprofundamento, considerei importante que fossem empregadas diferentes formas de obter e registrar informações, bem como de analisá-las. Assim, conciliei duas estratégias para reunir informações acerca do caso: observações e entrevista narrativa com Maria.

As observações, realizadas de forma contínua e sistemática durante o período da pesquisa de cunho etnográfico, já referida, foram registradas em diário de campo e por meio de imagens fotográficas. Tais registros compreendiam um tema mais abrangente do que a atual proposta de estudo, portanto, apenas alguns deles foram selecionados, considerando sua relevância para o caso de Maria e estes, organizados em sequência cronológica para posterior análise.

A inclusão da entrevista narrativa no percurso metodológico teve como objetivo uma aproximação da experiência, não da forma como eu a observei, mas sim da forma como foi vivida pela entrevistada, ou como foi registrada por sua memória.

Segundo Dutra,

a modalidade da narrativa mantém os valores e percepções presentes na experiência narrada, contidos na história do sujeito e transmitida naquele momento para o pesquisador. O narrador não "informa" sobre a sua experiência, mas conta sobre ela, dando oportunidade para que o outro a escute e a transforme de acordo com a sua interpretação, levando a experiência a uma maior amplitude, tal como acontece na narrativa. (DUTRA, 2002, p. 374).

Para as análises, reuni observações, e entrevista de forma articulada, buscando pontos convergentes ou divergentes entre minhas percepções como observadora e a narrativa da entrevistada. É importante salientar que as análises consideram não apenas os fatos narrados, mas 
também a forma como essa experiência reverberou na minha escuta, impregnada do referencial teórico estudado e das observações feitas.

Dutra (2002) destaca a complexidade envolvida na tarefa de compreender a experiência humana dada a subjetividade que constitui cada ser que sente, pensa e expressa através da linguagem sua própria existência. Conforme a autora, a experiência humana "é fluida, processual, semelhante e distinta de todas as outras, o que exclui a possibilidade de explicá-la através de verdades estáticas e aplicáveis a todos os outros seres" (DUTRA, 2002, p. 378). Nesse sentido, a entrevista narrativa sinaliza a possibilidade de preservar, dentro do possível, a dimensão da experiência vivida representada pela linguagem da entrevistada.

Goldenberg (2004) refere que a observação participante e as entrevistas em profundidade são procedimentos de pesquisa que têm suas origens em uma tradição de pesquisa antropológica nas sociedades primitivas. Segundo a autora, como os dados não são padronizados, não há como estabelecer com precisão o tempo adequado de pesquisa, podendo essa durar semanas ou anos, por exemplo, conforme o tema, o pesquisador e seus pesquisados (GOLDENBERG, 2004).

Na pesquisa em questão, as observações foram realizadas no período de março a dezembro de 2016, semanalmente, nas aulas de dança que tinham duração de duas horas, além dos ensaios, encontros culturais (palestras, festas de acampamento, viagens) e apresentações do grupo. A observação foi participante e envolveu conversas informais, que foram registradas em diário de campo, junto aos demais aspectos observados.

A entrevista narrativa foi desenvolvida em uma única sessão, com duração de aproximadamente duas horas, tempo no qual Maria conseguiu abordar as questões propostas em profundidade. O conteúdo foi gravado em arquivo de áudio, transcrito e posteriormente analisado.

A Resolução $n^{\circ} 510$ do Conselho Nacional da Saúde, esclarece que as pesquisas com participantes não identificados não são registradas nem avaliadas pelo sistema CEP/CONEP (GAYA et al., 2016). Nesse sentido, optei por utilizar o nome fictício de "Maria" para preservar a identidade do sujeito da pesquisa. Da mesma forma, os registros de imagem foram preservados, servindo apenas como material de análise, sem exposição pública.

$\mathrm{Na}$ intenção de manter a transparência durante todas as etapas da pesquisa, elaborei um termo de consentimento informado que foi assinado pela entrevistada e duas testemunhas. Neste termo constaram esclarecimentos sobre o tema abordado, procedimentos metodológicos e sobretudo sobre o direito de desistir a qualquer tempo ou mesmo de requerer indenização em caso de danos provenientes da investigação.

Além do período de observações e entrevista, a pesquisa envolveu três etapas: a revisão bibliográfica, a seleção, organização e análise das informações e finalmente, a escrita desse texto. As três etapas mencionadas ocorreram durante o ano de 2017, sendo que a escrita avançou até o mês de janeiro de 2018.

\section{Danças ciganas: mistérios e significados}

Durante o tempo que estive realizando a pesquisa de cunho etnográfico obtive, com esse grupo específico, muitas informações sobre a dança cigana e seus significados. Algumas foram novas descobertas para mim, baseadas na oralidade das pessoas com quem andei e nas práticas que observei, outras confirmaram o que já havia lido em fontes bibliográficas sobre o tema. A seguir, sem a pretensão de produzir verdades absolutas ou mesmo generalizações, compartilho o que aprendi.

A música e a dança estão presentes na cultura cigana, seja como forma de expressão dos sentimentos, ritual de conexão com a natureza e com a espiritualidade, seja como ferramenta de subsistência. Para os ciganos, a dança é uma manifestação de Deus, através do corpo e da alma. Nesse sentido, é utilizada de forma ritualística em festejos ou mesmo em ocasiões de profunda tristeza.

Pela reconhecida habilidade dos ciganos 
nessa área, e pela admiração que despertam, a dança também é utilizada de forma artística, sendo apresentada predominantemente nas ruas, em troca de contribuições espontâneas, ou em eventos fechados para os quais eventualmente são contratados. Além disso, dançar publicamente é uma forma de expressar sua cultura para o mundo, de uma forma positiva, como um contraponto a tantos preconceitos atribuídos ao povo cigano.

Segundo Kilkner,

todas as danças ciganas, mesmo as danças festivas, apresentam vínculo com o sagrado. Nem todas objetivam a prescrição de uma tradição cultural, ou revivem um mito de origem, mas inevitavelmente, pelas danças, solidificam-se memórias e as práticas corporais ciganas dão sentido à festa. (KILKNER, 2008, p.177).

Os ritmos ciganos são contagiantes, geralmente acompanhados de palmas e sapateados, ao som de guitarras, violas, violinos, acordeões, címbalos, castanholas e pandeiros. As músicas, as vestimentas e as danças, compõem uma cena alegre e envolvente, repleta de significados culturais.

As danças ciganas são ensinadas de geração para geração. Tanto na forma ritualística, como na forma artística, são praticadas por homens ou mulheres, individualmente, em casais ou grupos. Ao dançar, homens e mulheres utilizam movimentos distintos, expressando, de certo modo, papéis que assumem dentro da cultura cigana.

$\mathrm{Na}$ dança individual, os homens executam movimentos vigorosos, incluindo figuras de braço, giros e sapateados, como se observa, por exemplo, no flamenco, considerado uma modalidade de dança cigana. O olhar e a expressão facial sugerem força, alegria e na presença da mulher, contemplação, estando o olhar masculino voltado todo o tempo para seu par. Nas danças de casal, ou em grupo, atuam de certa forma, como coadjuvantes para a dança feminina, executando movimentos circulares e delicados em torno da mulher, sugerindo proteção, e também se posicionando imóvel, com um joelho ao solo ou de pé, servindo como eixo para os movimentos femininos. Não há toque entre homem e mulher durante a dança, exceto quando são casados, em situações eventuais.

Os ciganos podem utilizar adereços para a dança, como chapéus ou faixas longas, os quais são incluídos na coreografia ou na dança espontânea. O figurino para a dança masculina é o mesmo utilizado no dia a dia, dentro da cultura cigana: calças, camisas lisas ou estampadas, sapatos e eventualmente coletes. Adornos como pulseiras, correntes ou brincos de argola complementam o visual.

As mulheres executam, tanto nas danças individuais como nas danças de casal ou grupo, movimentos leves, delicados, incluindo dedos, mãos, braços, giros de peito, de corpo inteiro e passos suaves, que sugerem sensualidade. O olhar e a expressão facial é um elemento importante nessas danças, transmitindo força e mistério. No flamenco e em alguns estilos de dança cigana, mais específicos, os movimentos são mais firmes e incluem o sapateado. $\mathrm{Na}$ maioria das danças ciganas a mulher dança descalça, mantendo o contato dos pés com a terra, que na cultura cigana representa uma troca com esse elemento da natureza. De qualquer forma, preservam a sensualidade e a delicadeza, exacerbando sentimentos.

Valores como liberdade, alegria, amor e união são cultuados através da dança cigana e podem ser observados através das composições coreográficas. Além disso, muitos artefatos ${ }^{4}$ são utilizados na dança cigana, como rosas, leques, xales, echarpes, lenços, véus, fitas, punhais, espadas, pandeiros, castanholas, tochas, fogueiras, etc. Tais artefatos assumem papel primordial tanto nas coreografias, como nas danças espontâneas, pois estão relacionados a significados específicos e representam rituais da

4 Utilizo o termo "artefato" referindo-me ao conceito de artefato cultural. Hall (1997) afirma que a representação é uma prática que usa objetos e efeitos materiais, mas o significado depende não da qualidade material do signo, mas de sua função simbólica. $O$ artefato cultural consiste no próprio objeto, porém, considerando o que ele representa para uma determinada cultura. 
cultura cigana. Assim, as danças ciganas incluem a "dança das rosas", a "dança do leque", a dança do punhal", a "dança da fogueira" a "dança do véu" e tantas outras, conforme os elementos utilizados.

A dança das rosas, por exemplo, é executada predominantemente com rosas vermelhas que representam o amor, a beleza, a energia que vem da terra, a conquista e a sedução. Com rosas de outras cores, a dança das rosas assume outras intencionalidades, considerando que as cores para os ciganos também têm significados específicos. Com a sua dança, os ciganos compartilham a energia desse ritual, finalizando com a entrega da rosa, ou das rosas para alguém do público, conforme sua intuição definir. A pessoa leva consigo a lembrança da dança e a energia materializada na rosa.

O figurino da dança feminina, semelhante ao que se usa no dia a dia dos acampamentos ciganos, compreende saias longas, coloridas e rodadas (para a dança mais rodadas do que para o uso diário) - no mínimo duas sobrepostas - bombachinhas compridas por baixo das saias, blusas predominantemente com babados, ombros a mostra e fartos decotes, lenços com ou sem moedas na cintura, pés descalços, lenço nos cabelos para as mulheres casadas, flores ou outros adereços nos cabelos para as solteiras. Como complementos, brincos, pulseiras, anéis e colares em abundância. Para o flamenco, são utilizadas saias justas com babados a partir da altura dos joeIhos com blusas combinando em cores lisas, ou em estampas florais, de lunares ou com outras figuras geométricas. Também podem ser utilizados vestidos ou calças, conforme a necessidade da dança proposta.

As saias de ampla roda são fundamentais em algumas danças ciganas para a execução dos movimentos que representam a limpeza das energias do ambiente, o elemento ar, que dá vida e renova. O cumprimento longo e a utilização de duas saias além das bombachas têm a finalidade de cobrir as pernas, que de acordo com a cultura cigana, jamais devem ser expostas. Por outro lado, os decotes deixam muitas vezes parte dos seios à mostra, tendo em vista que esta parte do corpo representa fertili- dade e consiste num símbolo materno. Os cabelos, longos e soltos ou presos em tranças, representam, além da feminilidade, a honra da mulher cigana, portanto, precisam ser muito cuidados e preservados, sendo que em algumas comunidades ciganas, o adultério pode ser punido com o corte dos cabelos.

Considerando que as danças ciganas têm no corpo o local da expressão divina e que para os ciganos, Deus se manifesta mitologicamente, na personificação dos fenômenos naturais, a relação entre dança e elementos da natureza é direta. Cores, artefatos e movimentos corporais trazem para a dança cigana quatro elementos fundamentais da natureza - a terra, o ar, a água e o fogo - evocando suas energias para que aqueles que dançam e aqueles que assistem possam ser beneficiados na forma de ritual. Nessa direção, Lyz refere que

na tradição cigana o elemento fogo representa a sensualidade, demonstração viva do amor, da união, do calor humano e da harmonia, na dança, é representado com movimentos de serpente, ondulatórios de quadril, e também através das cores das roupas nos tons quentes (vermelho, laranja); o elemento água lava e limpa as suas vidas e os livra de toda carga negativa e interferência do comportamento; desbloqueia emoções, traz alegria e bem estar, este elemento é representado esteticamente através dos véus; já o elemento terra evoca a prosperidade, a renovação, a sobrevivência, a força e o equilíbrio, faz-se representar pelas batidas dos pés e movimento de representação de crescimento de uma árvore; e por fim, o elemento ar surge como o sopro mágico da vida, das energias físicas e da saúde, e é demonstrado na dança, através das ondulações das mãos. (LYZ, 2000, p. 45). 
De diferentes formas, esses elementos estão sempre presentes, assim como os artefatos culturais, que vão das peças do vestuário à forma de arrumar o cabelo. Num misto de arte e religiosidade, a dança cigana tem seu universo próprio e surpreende a cada descoberta, revelando seus mistérios.

Para além da prática de uma modalidade de dança, esse contexto rico em significados interpela os sujeitos que com ele se identificam e passam a ter uma experiência tão profunda, quanto transformadora. A mulher cigana, protagonista da dança, detentora dos seus mistérios, enfeitada, colorida, capaz de evocar energias da natureza, de transmitir alegria ou amenizar a tristeza, apta a exibir, ao mesmo tempo, força, leveza e sensualidade, eclode na dança e pode refletir mudanças significativas, que extrapolam a técnica ou a arte de dançar.

Segundo Hall, as identidades se constituem "do diálogo entre os conceitos e definições que são representados para nós pelos discursos de uma cultura e pelo nosso desejo (consciente ou inconsciente) de responder aos apelos feitos por esses significados" (HALL, 1997, p.26).

$\mathrm{O}$ autor trata ainda da produção de subjetividades afirmando que utiliza o termo identidade significando

o ponto de encontro, o ponto de sutura, entre, por um lado, os discursos e as práticas que tentam nos "interpelar", nos falar ou convocar para que assumamos nossos lugares como os sujeitos sociais de discursos particulares e, por outro lado, os processos que produzem subjetividades, que nos constroem como sujeitos aos quais se pode "falar". (HALL, 2000, p.111).

Assim, ao analisar representações presentes na dança cigana e, em especial, representações do feminino, busco o "ponto de sutura" entre tais representações e possíveis processos de subjetivação desencadeados em Maria.

\section{A dança como experiência: o caso de Maria}

Compreender a dança como experiência, exige um aprofundamento acerca desse conceito. Partindo do pressuposto de que nem toda a prática de dança constitui uma experiência para o sujeito, no sentido da "experiência" que pretendo adotar nesse texto, vale refletirmos sobre o termo. Larrosa, afirma que "a experiência é o que nos passa, o que nos acontece, o que nos toca. Não o que se passa, não o que acontece, ou o que toca" (LARROSA, 2002, p.21). Nessa perspectiva, podemos compreender o caráter pessoal da experiência, o quanto ela é particular para cada sujeito e por isso mesmo, produz diferentes marcas quando os toca. É possível concluir ainda, que nem tudo o que acontece, passa ou toca, chega a interpelar a todos da mesma forma, resultando para alguns em mero acontecimento e para outros numa experiência. Ainda que um grupo de pessoas participe do mesmo acontecimento, ao mesmo tempo e no mesmo espaço, a forma como esse acontecimento vai tocá-lo é única, contingente e pessoal.

Para Larrosa, "o sujeito da experiência seria algo como um território de passagem, algo como uma superfície sensível que aquilo que acontece afeta de algum modo, produz alguns afetos, inscreve algumas marcas, deixa alguns vestígios, alguns efeitos" (LARROSA, 2002, p.24). No entanto, o autor salienta que para isso aconteça, é preciso que o sujeito esteja "ex-posto", ou seja, que esteja aberto, disposto a um gesto de interrupção em tudo aquilo que põe, propõe, impõe, para permitir-se viver intensamente a experiência. Sobre esse aspecto, Maria refere na entrevista: "Não tirava folga, teve épocas que eu trabalhei de segunda a segunda e assim tu vais cansando. Hoje me dou esse momento. Digo não, terça-feira é sagrada! Então é meu momento!" (Trecho da entrevista realizada com Maria, 2017).

Larrosa (2002) destaca que o saber proveniente da experiência se dá na relação entre o conhecimento e a vida humana, de modo que esse saber não reflete verdade absoluta sobre o que 
são as coisas, mas sim, o sentido ou o sem sentido do que acontece. Nessa direção, ao pensar na dança como experiência, podemos afirmar que, a dança se deu como experiência para Maria a partir do momento que ela se expôs e se colocou como território de passagem, deixando aquele universo que a fascinava, se tornasse parte dela. Sobre o motivo que a levou até a dança, Maria respondeu:

Nunca tinha feito nenhum tipo de dança. Eu tentei fazer em 2002, 2003 dança do ventre. Então cheguei a fazer acho que um mês ou dois e tive que parar porque não tinha tempo e comecei a faltar. E aí tu ficas com aquela coisa. Vontade de fazer dança! Porque na dança tu consegue te soltar né? Sempre passava na frente da escola, de ônibus. E pensei, um dia vou descer aqui para ver quanto é e como funciona. (Trecho da entrevista realizada com Maria, 2017).

Tanto a dança do ventre, primeira tentativa de Maria, como a dança cigana tem como característica marcante a sensualidade da figura feminina. Ela menciona na entrevista a necessidade de "se soltar". Penso que essa característica pode ser um indicador do que ela estava procurando naquele momento: soltar a sensualidade, libertar aspectos de sua personalidade que estavam "presos". Não houve uma identificação maior na primeira tentativa, a ponto de motivá-la para prosseguir. Entretanto, o desejo persistiu e a levou para a dança cigana num segundo momento. Para Maria, aquela dança fazia sentido de um modo particular, e isso permitiu que saberes fossem agregados pela experiência.

Baseado em Foucault, Larrosa (1997) fala da experiência de si, afirmando que toda cultura transmite certo repertório de "modos de experiência de si" e todo novo membro de uma cultura precisa aprender a ser sujeito dessa cultura em alguma das modalidades incluídas nesse repertório. Maria não era de etnia cigana, mas queria aprender a dança e seus códigos. Estava dispos- ta a adquirir o repertório necessário e tornar-se membro - no que se refere à dança - dessa cultura.

Maria chegou demonstrando ti-
midez. la fazer uma aula experi-
mental. Estava vestida de preto,
saia longa e reta, blusa de gola
alta colada ao pescoço, botas
de cano curto. Ela usava ca-
belos curtos, mas com cumpri-
mento suficiente para estarem
presos bem esticados, escon-
dendo seu volume e os cachos
característicos dos cabelos
crespos, brincos pequenos e
nenhuma maquilagem visível.
Apresentou-se para o grupo es-
clarecendo que não era cigana,
mais amava tudo o que se rela-
cionava com esse povo e estava
pronta para aprender. Imediata-
mente tirou os sapatos, aceitou
uma saia emprestada pela pro-
fessora e sorriu demonstrando
satisfação de estar ali. (Tre-
cho do diário de campo, 2015).

A tecnologia de si implica a reflexão sobre os modos de vida, sobre as escolhas existenciais e sobre a maneira de autorregular a conduta, fixando para si mesmo os fins e os meios (FOUCAULT, 2003). Foucault define como técnicas de si

os procedimentos, que, sem
dúvida, existem em toda civili-
zação, pressupostos ou prescri-
tos aos indivíduos para fixar sua
identidade, mantê-la ou trans-
formá-la em função de determi-
nados fins, e isso graças a rela-
ções de domínio de si sobre si
ou de conhecimentos de si por
si. (FOUCAULT, 1997, p.109).

Assim, podemos compreender que a dança cigana consiste num procedimento, uma técnica de si, pela qual se aprende sobre "ser homem" ou "ser mulher" na cultura cigana. As prescrições sobre vestimentas, comportamentos, movimentos e todo o conjunto de elementos que compõem a representação proposta, apontam para uma identidade femi- 
nina ou masculina a ser mostrada. De algum modo, Maria se encantou e acolheu para si, ou para a sua dança, essa identidade. Na entrevista (2017), ainda falando sobre os motivos que à levaram à dança cigana, ela relata: "Fiz uma aula experimental e comecei, e aí me apaixonei. Porque é apaixonante a dança né? É uma coisa muito boa, tu te soltas, máxima. A mulher que estava escondida, ela brotou".

Relacionando as representações do feminino na dança cigana, com as tecnologias de si desencadeadas em Maria a partir dessa prática, podemos interpretar que "a mulher escondida" a qual ela se refere se identificava com o contexto apresentado e por meio da dança, libertou-se. Ao dançar, Maria conseguiu expressar o que estava oprimido, como se a dança fosse um grito de liberdade.

Em entrevista a Kilkner, ao ser questionado sobre o que significa a dança na sua cultura, o patriarca do clã cigano, Kalderash, responde: "A dança? A dança do nosso povo é um grito. Um grito que ecoa no tempo e no espaço" (KILKNER, 2008, p. 182 e 183). Maria foi interpelada por esse significado e "gritou" que havia uma outra mulher dentro dela.

Lyz afirma que a prática da dança cigana

tem servido para muitos, como terapia e melhor qualidade de vida ou como forma de liberação das emoções interiores, de dar vazão aos sentimentos e às íntimas necessidades, revelando o caráter e certos sentimentos (preguiça, timidez, depressão, desânimo...) dos praticantes, pois como é uma dança de corpo, mente e alma, esses sentimentos deverão ser trabalhados no decorrer do processo de cada um, através dos movimentos, postura, respiração e conscientização corporal. (LYZ, 2000, p. 58).

Na história de Maria, fica evidente que a dança Ihe proporcionou rever questões interiores e ter uma vida de maior qualidade, a partir da liberação do seu jeito de ser e dos seus desejos. Ao ser questionada sobre o que a dança cigana ensina, Maria respondeu:

Ela ensina, a dança cigana, a tu te amar mais. Te respeitar como mulher, te valorizar, ser mais sedutora. Tu não tens aquele medo de usar aquele batom vermelho e se importar com o que as pessoas vão pensar de ti. (...) Eu sempre fui uma pessoa muito mística e pessoas que já me conheciam há anos, dizem: "Bah! Até que enfim tu botaste para fora aquela mulher que estava escondida ai dentro! (Trecho da entrevista realizada com Maria, 2017).

Corroborando nesse sentido, Maia refere que a dança cigana "contribui para o aumento da autoestima, pois desperta, do ponto de vista psicológico e emocional, a alegria, força, altivez, sensualidade e beleza, destravando energias negativas e as transformando em energias positivas" (MAIA, 2013, p.21). A redução ou ampliação da autoestima pode ser percebida de muitas formas e relacionada a inúmeros fatores.

Maria relaciona a redução de sua autoestima, dentre outros fatores, ao trabalho que desenvolve como cuidadora de idosos:

Trabalho com a morte praticamente. Pego os pacientes já morrendo. Então tu não tens tempo pra te cuidar. Tu ficas em função de doença. Ah o cabelo tá branco e deixa! Tu passas um batonzinho e deu! Não pinta a unha e a unha descasca... ah depois eu faço! Porque tu vives muito no meio disso né? (Trecho da entrevista realizada com Maria, 2017).

Da mesma forma, relaciona à dança o resgate dessa autoestima:

Depois da dança não! Comecei a usar as bijuterias que não usava mais, comecei a usar roupas mais coloridas, mais alegres, deixar o cabelo crescer porque 
eu cortava curto por ser prático. Lavou tá pronto! Então assim, tu passas a te cuidar mais, depois que a dança dá aquele click dentro de ti, então acho que tu renasces. (Trecho da entrevista realizada com Maria, 2017).

Maria afirma que essa transformação aconteceu aos poucos. Conta que no início, modificava seu visual no dia da aula de dança: "Era o dia que eu ia para frente do espelho, fazer um reboco caprichado, tirar foto, fazer exposição de figura, me encher de pulseiras, de brincão". Depois, expandiu essa forma de se arrumar para todos os dias, independentemente de ter ou não aula de dança: "Não tô nem aí se estou nos lugares e estou com flor no cabelo, se estou com brincão, pulseira, saião, o que importa é eu me sentir bem, e não o que os outros vão achar! " A timidez deu espaço a uma mulher extrovertida, empoderada dos desejos que tinha em relação a si mesma e promoveu mudanças interiores, refletidas na aparência física. Sobre esse ponto de vista, Maria relata:

Como eu costumo dizer, em relação a exposição da figura, a gente não tem mais vergonha de expor a figura. Mais é mais! Então coisa boa chegar num lugar com as mulheres bonitinhas, simplesinhas e tu chegar bem cigana! Ver que te olharam! Então tu passas a chamar a atenção. A dança acrescenta muito no universo feminino, ela exerce esse poder de transformação, de um reencontro da gente. $E$ a alma da gente fica feliz também, tu passas a ver o mundo com outros olhos. Tu passas a ser mais alegre. Às vezes tu estás ouvindo uma música e não precisa ser música cigana, tu já sais dançando. Tu te soltas. Não tem mais vergonha de sair cantando, sair dançando. Então, essa é a magia da dança. (Trecho da entrevista realizada com Maria, 2017).
A dança é uma forma de expressão rica em significados. Tais significados são expostos não somente pelo repertório de movimentos executados, mas pelo conjunto de elementos que compõem a cena. Sobre o figurino, por exemplo, Vargas, Rieth e Pereira pontuam:

Temos estudado a importân-
cia do figurino como elemento
constituinte da cena, pois este
não pretende ser apenas uma
roupa e sim um instrumento ritu-
al do ator/bailarino para compor
com as regras da encenação
e interagir com o conjunto do
espetáculo, sendo a ligação en-
tre o corpo do artista e a pele
do personagem. (VARGAS;
RIETH; PEREIRA, 2016, p.9).

As roupas, os adereços, as cores, dão forma a uma imagem de mulher que Maria passou a querer representar também fora do espaço restrito à sala de danças ou ao palco. Desse modo, para que a personagem extrapolasse a cena da dança, foi preciso levar sua "pele" para outros espaços. Quando Maria diz "não ter mais vergonha" mostra a superação de um comportamento contido que Ihe desagradava. Demonstra prazer em ser vista, em chamar a atenção, pois seu jeito de ser agora está de acordo com o que deseja mostrar. Parece ter orgulho de si e da transformação pela qual passou através da dança.

A transformação de Maria chegou a refletir em aspectos que há algum tempo estava "adormecidos" na sua vida. Na entrevista ela conta que está de casamento marcado, pois "a nova Maria" trouxe para ela um novo amor. Ela reflete:

Tinha medo de me envolver com alguém. Quando a gente aprende a se amar, muda até o olhar da outra pessoa! Quando a gente não sabe se amar, vem um namorado e a gente se sujeita, muda a nossa personalidade, aquela pessoa vai podando a gente. Quando a gente se ama fala logo: "Oh eu sou assim! Quer? Não quer? 
Tchau pra ti! Eu me sinto bem assim". (Trecho da entrevista realizada com Maria,2017).

De qualquer forma, segundo Maria, o casamento não é o mais importante e sim a nova relação que estabeleceu com ela mesma. A nova Maria está feliz sozinha ou acompanhada, contanto que não lhe falte a dança!

\section{— Finalizando a dança: considerações finais}

Da mesma forma que Maria foi interpelada pela dança, fui interpelada como pesquisadora pela sua história. Impossível olhar para ela hoje - colorida, enfeitada, sorridente, falante - e não lembrar como era antes de começar a dançar. A mudança é visível! Tão visível, quanto inquietante. Afinal, que pesquisador se contentaria apenas com o que é visível? O que nos move, é justamente o invisível.

Não sei o que a antiga Maria teria a nos dizer e como ela nos contaria a sua história. Contudo, a nova Maria nos proporcionou uma profunda reflexão sobre o invisível. Falou-nos sobre o que tinha contido e sobre como aconteceu sua "libertação". Guiou-nos no percurso da pesquisa, reconstituindo sua imersão no universo da dança cigana, repleto de sentimentos: medos, receios, angústias, mas sobretudo superação. Tornou possível compreendermos que o elo entre o visível e o invisível nesse caso, foi a dança.

A Maria de roupas sóbrias e passos tímidos se revelou uma bailarina segura, com um brilho especial no olhar, de roupas coloridas e acessórios exuberantes! Ela não era mais a mesma, nem a sua dança. Ao vê-la entrar em cena, a transformação se tornava visível. A conexão de Maria com a música, com os passos, com o grupo de bailarinas não deixava dúvidas de que ela representava ali o resultado de um processo encantador de desenvolvimento, não somente em sua performance, mas na identidade feminina que assumia para si.

Certamente, não é possível produzir generalizações a partir do estudo apresentado, porém, podemos reconhecer o potencial que a dança tem, para promover reflexões, como tecnologia de si e desencadear transformações positivas. A dança como experiência de si pode levar os sujeitos a (re) encontros com seus mais íntimos desejos e servir ainda como um caminho na arte de expressá-los.

As representações do feminino, presentes na dança cigana são carregadas de misticismo e muito próprias da cultura desse povo. No entanto, foram ao encontro do que Maria buscava para naquele momento. A transformação se deu justamente por essa afinidade entre expectativas, desejos e elementos disponíveis na dança para materializá-los. Uma nova Maria evidenciou os resultados alcançados, nesse caso. Para Maria, a experiência teve um significado particular, que coincide com o significado da dança para a cultura cigana: representou um grito que ecoou naquele momento vivido, em diferentes espaços, na busca da liberdade.

\section{Referências}

CONSELHO NACIONAL DE SAUDE. Resolução 510. Abril, 2016. In: GAYA, A. C. A; GAYA, A. R.; REPPOLD FILHO, A. R.; CARDOSO, M.; BRASILIENSE, A. M.; SBRUZZI, G. Projetos de pesquisa científica e pedagógica: o desafio da iniciação científica. $1^{a}$ ed. Belo Horizonte: Casa da Educação Física, 2016.

DUTRA, E. A narrativa como uma técnica de pesquisa fenomenológica. Estudos de Psicologia.7(2), p.371-378. 2002.

FOUCAULT, M. Subjetividade e verdade. In: FOUCAULT, M. Resumo dos cursos do Collège de France (pp. 107-116). Rio de Janeiro: Jorge Zahar, 1997.

FOUCAULT, M. Ditos e Escritos, Vol. IV: estratégia poder saber. Rio de Janeiro: Forense Universitária, 2003.

GOLDENBERG, M. A arte de pesquisar. como fazer pesquisa. $8^{a}$ ed. Qualitativa em Ciências Sociais / Mirian Goldenberg. Rio de Janeiro: Record, 2004. 
HALL, S. A identidade cultural na pós-Modernidade. Tradução de Tomaz Tadeu da Silva e GuaAprovado: 06/02/2020 cira Lopes Louro. Rio de Janeiro: DP\&A, 1997.

HALL, S. Quem precisa de identidade? In: SILVA, T. T. da. (Org.). Identidade e diferença: a perspectiva dos estudos culturais. Tradução de Tomaz Tadeu da Silva. Petrópolis, RJ: Vozes, 2000.

KILKNER, R. A. R. Ciganos: peregrinos do tempo. Ritual, cultura e tradição. 2008. Tese (Doutorado em Multimeios). Universidade Estadual de Campinas, Instituto de Artes, Campinas/SP. 2008.

LARROSA, J. Tecnologias do eu e educação. In: Silva, Tomaz Tadeu. O sujeito da educação. Petrópolis: Vozes, 1997.

LARROSA, J. Notas sobre a experiência e o saber de experiência. Revista Brasileira de Educação n¹9. jan/fev/abr, 2002.

LYZ, S. A Magia da Dança Cigana. São Paulo: Berkana Editora, 2000.

MAIA, S. B. A dança cigana como prática artística e pedagógica. 2013. Trabalho de Conclusão de Curso (Licenciatura em Dança). Universidade Federal do Rio Grande do Norte. Natal - RN. 2013.

MERLEAU-PONTY, M. O visível e o invisível. Tradução de José Arthur Giannotti e Armando Mora d'Oliveira. São Paulo: Perspectiva, 1982.

MOLINA NETO, V.; TRIVIÑOS, A. N. D. S. (Org.). A pesquisa qualitativa em Educação Física: alternativas metodológicas. $2^{\mathrm{a}}$ ed. Porto Alegre: UFRGS/ SULINA, 2004.

VARGAS, L. A. D.; RIETH, T. R.; PEREIRA, A. L. N. Vestido de Cena. V Encontro de Graduações em Dança do RS. Universidade Federal do Rio Grande do Sul. Porto Alegre - RS. 2016. 